\title{
The Exchange Rate Volatility in Indonesia and Policy Response
}

\author{
Ph.D. Candidate Ferry Syarifuddin (Bank Indonesia, Indonesia)
}

\begin{abstract}
High fluctuation of exchange rate in short horizon is obviously making economic activity more risky as uncertainty rises. Moreover, volatile exchange rates also make commodity prices, interest rates and a host of other variables more volatile as well. Although changes in long-run exchange rates tend to undergo relatively gradual shifts, in the shorter horizon, the exchange rate might be very volatile. Then there should be a systematic and measured policy to mitigate the foreign exchange fluctuations and to minimize the fluctuations as well as to drive it to its fundamental value. In this part, USD/IDR volatility is investigated using GARCH approach. The results reveal that, USD/IDR volatility in Indonesia is persistent. On the other hand, the following studies also present the outcomes of effectiveness of policy response by the Central Bank. Foreign-exchange sale interventions by the Central Bank lead conditional volatility of the USD/IDR to decrease slightly.
\end{abstract}

\section{Introduction}

One of consequences adopting floating exchange rate, many countries face often widely fluctuation of their exchange rate as capital flows freely coming in or out the countries. Freely floating exchange rate will be needed by independent monetary authority to conduct independent monetary policy. However, many countries usually reluctant to allow their currencies to fluctuate (e.g. Calvo and Reinhart 2000), because of the potential for sharp exchange-rate movements to exacerbate inflationary pressures and financial sector vulnerabilities.

The Bretton Woods exchange rate system fail has led to significant fluctuation in both real and nominal exchange rates. The liberalization of capital flows and the associated intensification of cross-border financial transactions also appear to have amplified the volatility of exchange rates and the misalignment movement of exchange rate from its fundamental value.

Some factors that cause the supply and demand of foreign exchange include market fundamentals (economic variables) such as inflation rates, productivity, real interest rates, consumer preference, government trade policy, and market expectations such as news about future market fundamentals and traders' opinion about future exchange rates. In the short run, foreign-exchange transactions are dominated by transfers of assets (bank accounts, government securities) that respond to differences in real interest rates and to shifting expectations of future exchange rates. Over the medium run, exchange rates are governed by cyclical factors such as cyclical fluctuations in economic activity. Over the long-run, foreign-exchange transactions are dominated by flows of goods, services, and investment capital, which respond to forces such as inflations rates, investment profitability, consumer tastes, productivity, and government trade policy (Carbaugh, 2013).

Foreign exchange rates can move in opposite direction from that indicated by longer-term fundamentals in the short run. This phenomenon exists mainly driven by heterogeneous foreign-exchange expectations by the foreign-exchange player. Besides, the free foreign exchange market mechanism and foreign-exchange system play main role in the dynamics of the foreign-exchange rates. Although today's exchange rate may be out of line with long-term fundamentals, this should not be construed as implying that is necessary inconsistent with shortterm determinants - for example, interest rate differentials, which are among the relevant fundamentals at the short end of the time dimension.

Indonesia is among of countries that adapts free floating exchange rate regime. By freely floating exchange rate and position as small open economy, Indonesia' exchange rate movements are strongly influenced by capital flows and net export's proceed. Hence, existence of central bank optimal monetary response (i.e. foreign exchange intervention) needed to drive the exchange rate for the long-term equilibrium exchange rate as well as to maintain its stability. Within the last 3 years, the IDR performed worse even though experienced mild volatility among regional economies. Even though, IDR experienced highest depreciation among regional economies caused by deteriorating current account and fiscal balance.

Since Indonesia has been adopting a floating exchange rate regime in the wake of the 1997 economic crisis, the value of the rupiah continues to be volatile and determined by fundamental and non-fundamental forces. Exchange rate is determined by supply and demand of foreign exchange in a free foreign exchange market that cause exchange rate fluctuate to appreciate or depreciate. Exchange rate volatility can have a negative effect on economy mainly through international trade and capital flows, directly through uncertainty and adjustment costs, and indirectly through its effect on the allocation of resources and government policies. If exchange rate movements are not fully anticipated, an increase in exchange rate volatility may lead risk-averse agents to reduce their international trading activities (Chit, 2010).

Therefore, it appears that the central bank has been prepared to intervene in order to prevent sharp currency movements in both directions, while buying/selling foreign exchange on a more sustained basis in an attempt to stabilize domestic price as well as to foster export competitiveness through the maintenance of a low, stable 
exchange rate. In some instances the Indonesian authorities have openly acknowledged their role in managing the exchange rate, particularly when intervening to support the currency in periods of sharp depreciation. In these cases intervention often appears to be carried out under the pretext of "keeping volatility in check". Indeed, it seems to be widely accepted that intervention is a valid policy tool, which can be used, "possibly in conjunction with monetary policy, to stabilize market expectations, calm disorderly market, and limit unwarranted short term exchange rate movements because of temporary shocks" (Warjiyo 2005). The role in maintaining exchange rate stability is also as a reflection of Bank Indonesia awareness of public pressure to manage the exchange rate at an appreciated level which support the desired inflation target. Economic agents monitor exchange-rate development every day and hope stable exchange rate overtime. Therefore, it is crucial for the central bank to fulfill the public's desire and this success in maintaining exchange-rate stability may be regarded by some policy-makers as a key indicator of central bank performance.

Primary source for measuring the volatility of an exchange rate, distribution of exchange rate data, has important implications for several financial models and is characterized by mild and volatile periods. Two proposed processes, autoregressive conditional heteroscedasticity (ARCH) by Engle (1982) and general autoregressive conditional heteroscedasticity $(\mathrm{GARCH})$ by Bollerslev (1986) have been shown to provide a good fit for many exchange rate series in the literature, allowing volatility shocks to persist over time by imposing autoregressive structure on the conditional variance. This persistence is consistent with periods of relative volatility and tranquility in returns and it is employed to explain the non-normalities in exchange rate series.

Therefore, it is crucial to observe and interpret the underlying reasons for volatility as well as measuring it. Utilizing ARCH/GARCH models, this study tries to measure and explain the volatility in the USD/IDR exchange rate level. Primary source for measuring the volatility of an exchange rate has important implications for several financial models and is characterized by mild and volatile periods.

\section{The Volatility of Financial Time Series Data: The Theory and Empirical Evidences}

Financial time series are often available at a higher frequency than macroeconomic time series and have been shown to exhibit the presence of statistically significant correlations between observations that are a large distance apart. Another distinguishing feature of many financial time series is time-varying volatility or "heteroscedasticity" of the data.

When discussing the volatility of time series, econometricians refer to the conditional variance of the data, and the time-varying volatility typical asset returns are otherwise known as conditional heteroscedasticity. The concept of conditional heteroscedasticity is introduced to economists by Engle (1982), who proposes a model in which the conditional variance of a time series is a function of past shocks; the autoregressive conditional heteroscedasticity (ARCH) model.

\subsection{Measuring Volatility: ARCH/GARCH Model}

In this part of the study, the stylized facts concerning the properties of financial time series are examined and the ARCH family models, which can capture periods of turbulence and tranquility, are investigated. One aspect to elaborate in this study is presenting the review of empirical findings that are attained by employing GARCH models on exchange rate series. GARCH is often used in quantitative financial research, where a trader predicts this period's by forming a weighted average of a long term average (the constant term), from information about the volatility observed in the previous period (the ARCH term), and the forecasted variance from the last period (the GARCH term). This model is also consistent with the volatility clustering often seen financial returns data, where large changes in returns are likely to be followed by further large changes.

The concept of ARCH disturbances was introduced by Engle (1982). This concept may successfully be applied in models for volatile markets. in speculative markets like exchange rates and stock markets you can observe that large and small errors tend to occur in clusters. It looks something like 'autocorrelation in the heteroscedasticity'. Engle formulated the notion that information from the recent past might influence the conditional disturbances variance. Therefore, the conditional variance, or the volatility, of a variable will be modeled. Engle postulated the following relationship, which would be known as an ARCH(p) model:

$$
\sigma_{u_{t}}^{2}=\alpha_{0}+\alpha_{1} u_{t-1}^{2}+\cdots+\alpha_{p} u_{t-p}^{2}
$$

ARCH provided a framework for analysis and development of time series models of volatility. However, ARCH models themselves have rarely been used in the last decade or more, since they bring with a number of difficulties as outlined by Brooks (2002) such as: how to decide the number of lags of the squared residuals in the model; how to decide the number of the squared errors that are required to capture all the dependence in the conditional variance that might be very large; and non-negativity constraint might be violated. Therefore, a natural extension of an ARCH(p) model which overcomes some of these problems is a GARCH model. Meanwhile, as a way to model persistent movements in volatility without estimating a very large number of coefficients in a high-order polynomial $\alpha(\mathrm{L})$. Bollerslev and Taylor (1986) suggested a GARCH model. The 
GARCH model allows the conditional variance to be dependent upon previous own lags, so that the conditional variance equation in the simplest case is now

$$
\sigma_{t}^{2}=\alpha_{0}+\alpha_{1} u_{t-1}^{2}+\beta \sigma_{t-1}^{2}
$$

Since the model is no longer of the usual linear form, OLS cannot be used for GARCH model estimation. There are a variety of reasons for this, but the simplest and most fundamental is that OLS minimizes the residual sum squares. The RSS depends only on the parameters in the conditional mean equation, and not the conditional variance, and hence RSS minimization is no longer an appropriate objective.

In order to estimate models from the GARCH family, maximum likelihood is employed. Essentially, the method works by finding the most likely values of the parameters given the actual data. More specifically, a loglikelihood function is formed and the values of the parameters that maximize it are sought. Maximum likelihood estimation can be employed to find parameter values for both linear and non-linear models.

In the context of conditional heteroscedasticity models, the model is $\mathrm{y}_{\mathrm{t}}=\mu+\varphi \mathrm{y}_{\mathrm{t}-1}+u_{t}, u_{t \sim} \mathrm{N}\left(0, \sigma_{\mathrm{t}}^{2}\right)$, so that the variance of the errors has been modified from being assumed constant, $\sigma^{2}$, to being time-varying, $\sigma_{t}^{2}$, with the equation for the conditional variance as previously. The $L L F$ relevant for a GARCH model can be constructed in the same way as for the homoscedastic case by replacing.

$$
\frac{T}{2} \log \sigma^{2}
$$

with the equivalent for time-varying variance

$$
\frac{1}{2} \sum_{t=1}^{T} \log \sigma_{t}^{2}
$$

and replacing $\sigma^{2}$ in the denominator of the last part of the expression with $\sigma^{2}$. Intuitively, maximizing the $L L F$ involves jointly minimizing

$$
\sum_{t=1}^{T} \log \sigma_{t}^{2}
$$

and

$$
\sum_{t=1}^{T} \frac{\left(y_{t}-\mu-\emptyset y_{t-1}\right)^{2}}{\sigma_{t}^{2}}
$$

(since these terms appear preceded with a negative sign in the $L L F$, and $-\frac{T}{2} \log (2 \pi)$ is just a constant with respect to the parameters). Minimizing these terms jointly implies minimizing the error variance (Brooks, 2002).

\subsection{Foreign Exchange Volatility: The Empirical Literatures}

There are many studies concerning exchange rate volatility. On one part, the study concerns mostly in investigating the impact of exchange rate volatility on economic variables. On the other part, the study investigates the sources of the volatility. However, among other things (such as the subject of study), they differ in the way of modeling exchange rate volatility. According to this modeling, they can be divided into two groups - the ones that use various modifications of standard deviations and the ones that use modifications of the ARCH approach.

Two economists - Belke and Setzer (2003) - investigate the impact of foreign-exchange volatility on the labor market. In their case, the exchange rate volatility is measured as the standard deviation of the 12 month-to-month changes in the logarithm of the spot rate. Meanwhile, Dell'Ariccia (1999) studies the effect of exchange rate volatility on bilateral trade flows. He uses not only the standard deviation of the first difference of the logarithmic exchange rate but also employs two other measures - the sum of the squares of the forward errors and the percentage difference between the maximum and minimum nominal spot rate. Other similar studies performed by Kenen, Rodrik, 1986, Koray, Lastrapes, 1989, Chowdhury, 1993, Kóbor, Székely, 2004, and Bulí, 2005 that model the exchange rate volatility as the moving sample standard deviation of the growth rate of the real exchange rate.

Baum et al. (2004) analyzes the impact of exchange rate volatility on the volume of bilateral exports. Quite similarly, Choudhry (2005), investigates the influence of exchange rate volatility on real exports, apply the GARCH model for measuring volatility. Kocenda and Valachy (2006), analyzing recent developments in exchange rate volatility in the Visegrad Group countries, suggest usage of the leverage GARCH model. Moreover, exchange rate volatility and the TARCH model are analyzed also in studies by Kocenda (1998) and McKenzie (2002). Although the TARCH approach is mostly employed in papers analyzing stock price movements, Kocenda (1998) claims that with regard to risk there is almost no difference between holding foreign exchange and equity. For this reason, he stresses the justification of using the TARCH approach also for modeling exchange rate volatility. Thus, this latter approach-ARCH- is plausible also for this research because its modification allows for an asymmetric, i.e., more realistic, impact of news on exchange rate volatility. 
The following three papers are similar in focusing on the same objects - the Visegrad Group countries. Kóbor and Székely (2004) study volatility using a Markov regime-switching model which allows them to identify periods of highly and lowly volatile exchange rates. Not surprisingly, their results say that volatility between these periods changes and is lower in lowly volatile periods. They also claim that there are substantial differences in volatility among the four countries. Bulí (2005) looks at the relationship between exchange rate volatility and financial market liberalization and concludes that liberalization significantly contributes to the stability of the exchange rates in all four countries. Kocenda and Valachy (2006) compare exchange rate volatility between fixed and floating regimes. Their findings confirm natural expectations that volatility increases under a less tight, i.e., floating regime. Moreover, they augment the TARCH model by inclusion of an interest rate differential and its inter-temporal change in order to account for their impact on volatility. They claim asymmetric decreasing effects of news on exchange rate volatility, as well as contemporaneous impact of the interest differential.

Aysoy et al. (1996) assess the daily exchange rates in the Turkish foreign exchange market within the framework of volatility and day-of-the week effect for the period January 1988 to December 1995. They find that the volatility of the Turkish foreign exchange market is low except instability and crisis period and all week days are significant in US dollar and German mark return series according to the GARCH $(1,1)$ model with a crisis dummy in variance function. The other study performed by Akcay et al. (1997) search for the currency substitution's effect on exchange rate instability in Turkey using EGARCH-M model for the period January 1987 to March 1996. Their results assert that the higher the dollarization, the higher is the volatility of the exchange rate. Moreover, the ARCH-M coefficient is positively significant implying that an increase in the conditional variance of depreciation will increase the mean of depreciation series itself. Guleryuz (1998) examines the period between January 1989 and April 1998 under different models and offered the ARMA(2,2)-ARCH(2) with dummy on Thursday in variance model as the best explaining model according to significance of parameters, R2, AIC and SBC. On the other hand Tuna (2002) investigates the relationship between CBRT monetary policies and exchange rate volatility using ARCH (1) model.

In the case of Turkish, Domac and Mendoza (2002), Agcaer (2003), Guimarães and Karacadag (2004) and Akinci et al. (2005a) and (2005b) investigate the effectiveness of interventions in Turkey in the aftermath of float in February 2001. Domac and Mendoza (2002) investigate the impact of CBRT's auctions on exchange rate volatility for the period February 22nd 2001 to May 30th 2002. They employ EGARH model in order to investigate the distinguishing effects of sale auctions on the conditional variance. To signal exchange policy intentions, a dummy is included which takes a value of unity on the day of public report. Moreover, overnight interest rate is added to the model in order to discover the effects of auctions in the money market. Their results suggest that overall central bank auctions have reduced the conditional variance. However, when the impact of auctions is studied separately, the reduction of volatility is a result of sales and purchase operations do not seem to have statistically significant effect on volatility of exchange rate. Furthermore, the results imply that an increase in the overnight interest rate has a negative effect on exchange rate volatility.

\section{Application of Volatility Models to Indonesia}

\subsection{Measure of Volatility}

Regarding the dependent variable, i.e., the volatility of exchange rates, the general autoregressive conditional heteroskedasticity $(G A R C H)$ model, is employed. This model comprises a leverage term that allows for the asymmetric effects of good and bad news. The $\operatorname{GARCH}(p, q)$ model is specified as:

$$
\begin{gathered}
r_{t}=a_{0}+\sum_{i=1}^{p} a_{i} r_{t-i}+\sum_{i=0}^{Q} b_{i} \varepsilon_{t-i} ; \varepsilon_{t} \sim N\left(0, \sigma_{t}^{2}\right) \\
\sigma_{t}^{2}=\omega+\sum_{i=1}^{p} a_{i} \varepsilon_{t-1}^{2}+\sum_{i=1}^{q} \beta_{i} \sigma_{t-1}^{2}
\end{gathered}
$$

where variable $r_{t}$ is the exchange rate return over two consecutive trading days, and $\sigma_{t}^{2}$ is the conditional variance that is a function of not only the previous realizations of $\varepsilon_{t}$, but also the previous conditional variances. The additional restriction $\sum_{i=1}^{p} a_{i}+\sum_{i=1}^{q} \beta_{i}<1$ is a sufficient and necessary condition for stability of the conditional variance.

\subsection{Overview of the Data}

A broad consensus has emerged that nominal exchange rates over the free float period are best described as non stationary, or specifically I (1), type processes: see e.g. Baille and Bollerslev (1989b). Therefore in this empirical study, exchange rate series is calculated as the daily difference in the logarithm form:

$$
D l f x=\ln f x_{t}-\ln f x_{t-1} \text { or }\left(\mathrm{fx}_{\mathrm{t}} / \mathrm{fx}_{\mathrm{t}-1}\right)-1
$$

The foreign exchange rate data $(f x)$ are the daily market foreign exchange closing rate for 1 USD. Data consist of daily prices from 3 January 2008 and 31 December 2013, for a total of 1,564 observations excluding 
weekends and holidays. In fact, the sampled period offers clear picture as it includes both appreciation and depreciation periods, and both selling and purchasing foreign-exchange interventions by BI.

Graphical illustration of the data in Figure 1 displays volatility clustering which means that there are periods of high and low variance.

R_SPOT

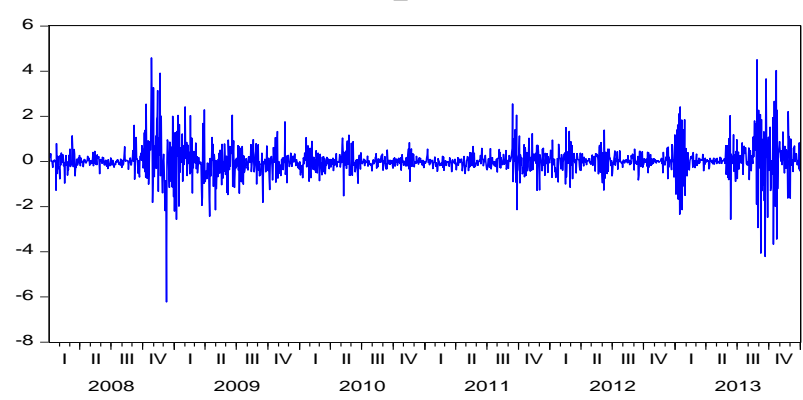

Figure 1 Volatility in USD/IDR series (daily return)

Before modeling time series data, it is important to check stationarity of the data. In order to test the stationarity of the series three different unit root tests: (1) the Augmented Dickey-Fuller (ADF) test with optimal lag length determined by both the Schwarz Info Criterion and Akaike Info Criterion, (2) the Phillips-Perron (PP) test, and (3) the Kwiatkowski-Phillips-Schmidt-Shin (KPSS) test are employed. While the ADF and PP test statistics test the null hypothesis that exchange rate return series contains a unit root, KPSS statistics test the null hypothesis that series is stationary. The tests are repeated with constant term and with constant and trend terms. Table 1 displays the results of the tests and all tests indicate the stationarity of the return of the foreign exchange rate series denoted with $R_{-} \operatorname{Spot}_{\mathrm{t}} \mathrm{I}(0)$.

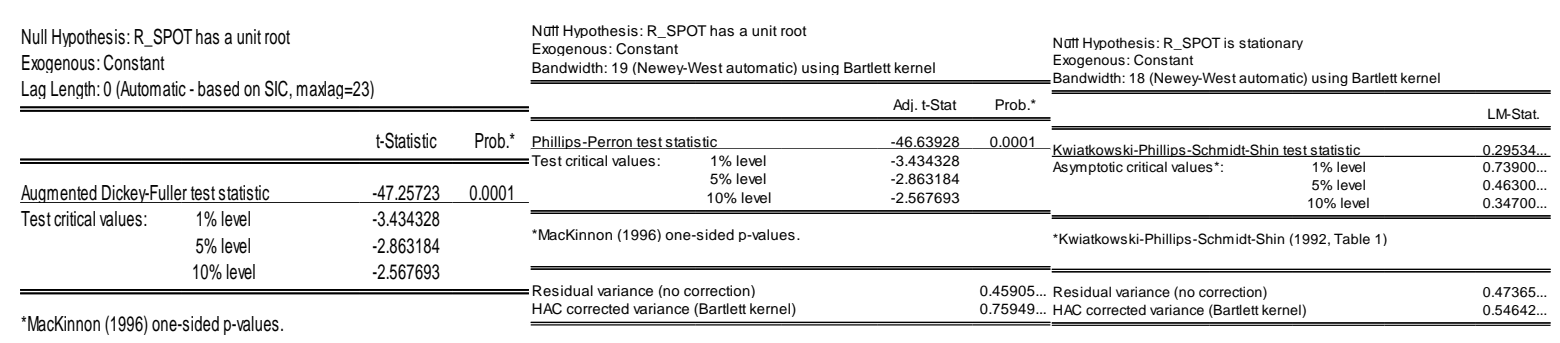

Table 1 Unit Root Tests

Additionally, Table 3 reports the Ljung-Box-Pierce Q statistics of autocorrelation of the deviations and the squared deviations of exchange rate series from its sample mean. Ljung-Box-Pierce Q statistics carries out the Breusch-Godfrey Lagrange multiplier test for high-order serial correlation. While the Q-statistic of the deviations employed to detect autocorrelation, $\mathrm{Q}$-statistic of the squared deviations $\left(\mathrm{Q}^{2}\right)$, are employed to test the volatility clustering or ARCH effects. For the exchange rate series, the statistics are calculated for lags up to 36 days. According to the results, there is serial correlation and $\mathrm{Q}^{2}$ statistic displays strong evidence of ARCH effect. The null hypothesis of the test is that there is no serial correlation in the residuals up to the specified order. Rejection of the null hypothesis implies volatility clustering in the series.

\section{Impact of Central Bank's Foreign Exchange Interventions}

Generally, the literature investigating Indonesia experiences focused on the effectiveness of the Bank Indonesia (BI) interventions in general. Differently, in this study the impact of the Bank Indonesia's sell of foreign-exchange intervention (d_Int_sell_spot) and other possible relevant variable such as NDF rate and real interest rate differential (RIRD), will be examined. Therefore, the following model is proposed to model mean of the exchange rate returns and conditional volatility as follows:

For GARCH $(1,1)$

$$
\begin{aligned}
& R_{-} S p o t_{t}=a_{0}+a_{1} R_{-} S p o t_{t-1}+a_{2} R_{-} N D F_{t}+a_{3} R I R D_{t}+a_{4} D \_I N T * S e l l \_S p o t_{t}+\varepsilon_{t} \\
& \varepsilon_{t} \mid \Omega_{t-1} \sim N\left(0, h_{t}\right)
\end{aligned}
$$

$$
h_{t}=b_{0}+b_{1} R_{-} S p o t_{t-1}+b_{2} R_{-} N D F_{t}++b_{3} R I R D_{t}+b_{4} D_{-} I N T * S e l l \_S p o t_{t}+\alpha \varepsilon_{t-1}^{2}+\beta h_{t-1}
$$

where $b_{0}, \alpha, \beta>0$ dan $\alpha+\beta<1$ 


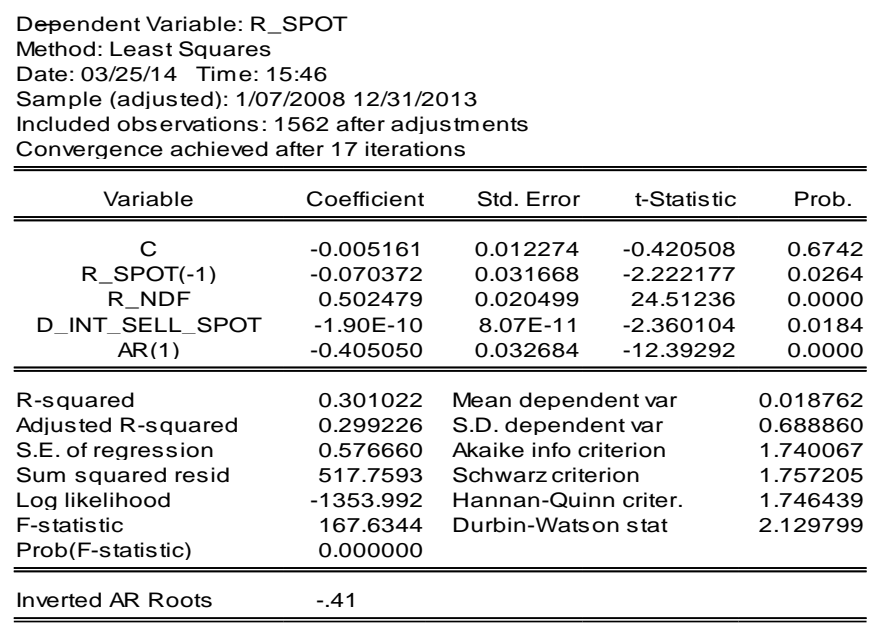

Table 2 Mean Equation and Pre-estimation Test Results

Date: $03 / 25 / 14$ Time: $15: 47$
Sample: $153 / 2008$ 12131/2013
Includeded observations: 1562

Q-statistic probabilities adjusted for 1 ARMA term and 1 dynamic regressor

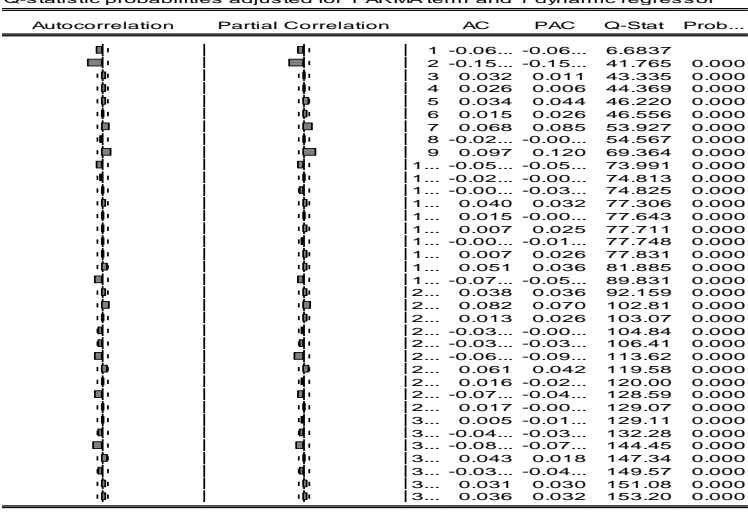

Date: $03 / 25 / 14$ Time: $15: 48$
Sample: 1/03/2008 12/31/2013
Included observations: 1562

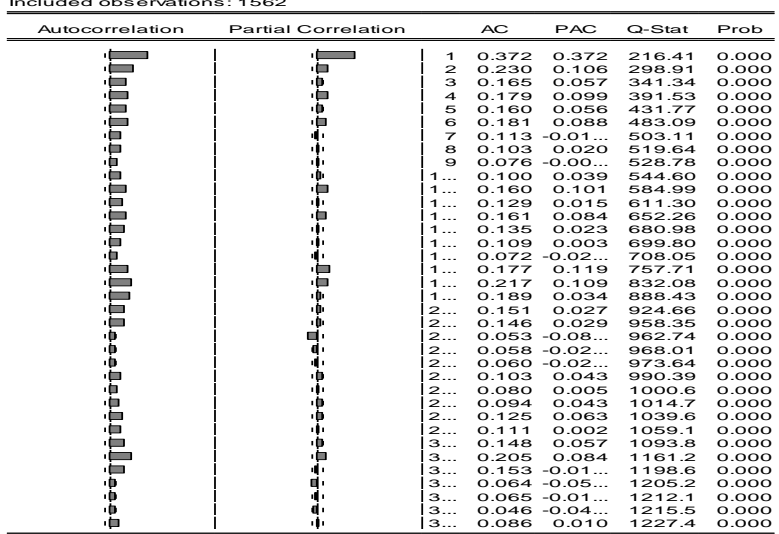

Table 3 Q Statistics of Deviations and Squared Deviations

Heteroskedasticity Test: ARCH

\begin{tabular}{llll}
\hline \hline & & & \\
F-statistic & 250.1833 & Prob. F $(1,1559)$ & 0.0000 \\
Obs*R-squared & 215.8633 & Prob. Chi-Square(1) & 0.0000 \\
\hline
\end{tabular}

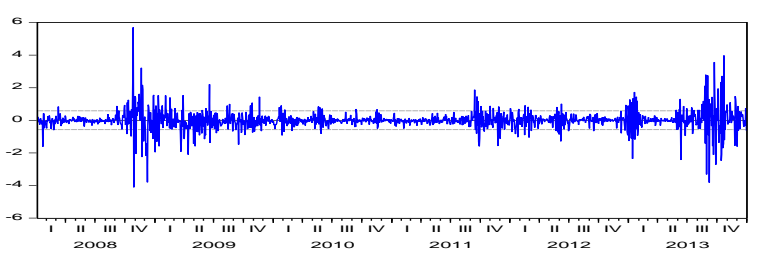

R_SPOT Residuals

Figure 2 Error Terms from the OLS estimation of mean equation

\begin{tabular}{|c|c|c|c|c|c|c|c|c|c|}
\hline \multicolumn{5}{|c|}{$\begin{array}{l}\text { Dependent Variable: R_SPOT } \\
\text { Method: ML - ARCH (Marquardt) - Normal dis tribution } \\
\text { Date: } 04 / 03 / 14 \text { Time: } 15: 51 \\
\text { Sample (adjusted): } 1 / 04 / 200812 / 31 / 2013 \\
\text { Included observations: } 1563 \text { after adjustments } \\
\text { Convergence achieved after } 23 \text { iterations } \\
\text { MA Backcast: } 1 / 03 / 2008 \\
\text { Presample variance: backcast (parameter }=0.7) \\
\text { GARCH }=C(6)+C(7)^{\star} \operatorname{RESID}(-1)^{\wedge} 2+\mathrm{C}(8)^{*} \mathrm{GARCH}(-1)\end{array}$} & \multicolumn{5}{|c|}{$\begin{array}{l}\text { Dependent Variable: R_SPOT } \\
\text { Method: ML - ARCH (Marquardt) - Normal distribution } \\
\text { Date: O4/02/14 Time: } 09: 28 \\
\text { Sample (adjusted): } 1 / 04 / 200812 / 31 / 2013 \\
\text { Included observations: } 1563 \text { after adjustments } \\
\text { Convergence achieved after } 30 \text { iterations } \\
\text { MA Backcast: } 1 / 103 / 2008 \\
\text { Presample variance: backcast (parameter }=0.7) \\
\text { GARCH }=\mathrm{C}(7)+\mathrm{C}(8)^{*} \mathrm{RESID}(-1)^{\wedge} 2+\mathrm{C}(9)^{*} \mathrm{GARCH}(-1) \\
\end{array}$} \\
\hline Variable & Coefficient & Std. Error & $z$-Statistic & Prob. & Variable & Coefficient & Std. Error & z-Statistic & Prob. \\
\hline $\begin{array}{c}\text { C } \\
\text { R_SPOT(-1) } \\
\text { R_NDF } \\
\text { RIRP } \\
\text { MA(1) } \\
\end{array}$ & $\begin{array}{r}0.008845 \\
0.092872 \\
0.825879 \\
-0.001735 \\
-0.850732 \\
\end{array}$ & $\begin{array}{l}0.001836 \\
0.014765 \\
0.013501 \\
0.000355 \\
0.013772 \\
\end{array}$ & $\begin{array}{r}4.817803 \\
6.289968 \\
61.17184 \\
-4.883738 \\
-61.77261 \\
\end{array}$ & $\begin{array}{l}0.0000 \\
0.0000 \\
0.0000 \\
0.0000 \\
0.0000 \\
\end{array}$ & $\begin{array}{c}\text { C } \\
\text { R_SPOT(-1) } \\
\text { R_NDF } \\
\text { RIRP } \\
\text { D_INT_SELL_SPOT } \\
\text { MA(1) }\end{array}$ & $\begin{array}{r}0.007264 \\
0.086931 \\
0.826566 \\
-0.001672 \\
-2.39 E-11 \\
-0.852687\end{array}$ & $\begin{array}{l}0.002191 \\
0.014892 \\
0.013541 \\
0.000363 \\
1.13 E-11 \\
0.013576\end{array}$ & $\begin{array}{r}3.316170 \\
5.837543 \\
61.04295 \\
-4.604007 \\
-2.116583 \\
-62.80717 \\
\end{array}$ & $\begin{array}{l}0.0009 \\
0.0000 \\
0.0000 \\
0.0000 \\
0.0343 \\
0.0000\end{array}$ \\
\hline \multicolumn{5}{|c|}{ Variance Equation } & \multicolumn{5}{|c|}{ Variance Equation } \\
\hline $\begin{array}{c}\mathrm{C} \\
\operatorname{RESID}(-1)^{\wedge} 2 \\
\operatorname{GARCH}(-1) \\
\end{array}$ & $\begin{array}{l}0.001875 \\
0.326905 \\
0.741945 \\
\end{array}$ & $\begin{array}{l}0.000241 \\
0.019681 \\
0.011254 \\
\end{array}$ & $\begin{array}{l}7.777834 \\
16.61028 \\
65.92708 \\
\end{array}$ & $\begin{array}{l}0.0000 \\
0.0000 \\
0.0000 \\
\end{array}$ & $\begin{array}{c}\mathrm{C} \\
\operatorname{RESID}(-1)^{\wedge} 2 \\
\operatorname{GARCH}(-1)\end{array}$ & $\begin{array}{l}0.001808 \\
0.334430 \\
0.738989 \\
\end{array}$ & $\begin{array}{l}0.000249 \\
0.019860 \\
0.011318 \\
\end{array}$ & $\begin{array}{l}7.252091 \\
16.83924 \\
65.29129 \\
\end{array}$ & $\begin{array}{l}0.0000 \\
0.0000 \\
0.0000 \\
\end{array}$ \\
\hline $\begin{array}{l}\text { R-squared } \\
\text { Adjusted R-squared } \\
\text { S.E. of regression } \\
\text { Sum squared resid } \\
\text { Log likelihood } \\
\text { Durbin-Watson stat }\end{array}$ & $\begin{array}{r}0.329354 \\
0.327632 \\
0.564681 \\
496.7904 \\
-414.7979 \\
2.163384\end{array}$ & \multicolumn{2}{|c|}{$\begin{array}{l}\text { Mean dependent var } \\
\text { S.D. dependent var } \\
\text { Akaike info criterion } \\
\text { Schwarz criterion } \\
\text { Hannan-Quinn criter. }\end{array}$} & $\begin{array}{l}0.018866 \\
0.688651 \\
0.541008 \\
0.568414 \\
0.551197\end{array}$ & $\begin{array}{l}\text { R-squared } \\
\text { Adjusted R-squared } \\
\text { S.E. of regression } \\
\text { Sum squared resid } \\
\text { Log likelihood } \\
\text { Durbin-Watson stat }\end{array}$ & $\begin{array}{r}0.330173 \\
0.328022 \\
0.564517 \\
496.1835 \\
-413.3172 \\
2.152718 \\
\end{array}$ & \multicolumn{2}{|c|}{$\begin{array}{l}\text { Mean dependent var } \\
\text { S.D. dependent var } \\
\text { Akaike info criterion } \\
\text { Schwarz criterion } \\
\text { Hannan-Quinn criter. }\end{array}$} & $\begin{array}{l}0.018866 \\
0.688651 \\
0.540393 \\
0.571224 \\
0.551855\end{array}$ \\
\hline Inverted MA Roots & .85 & & & & Inverted MA Roots & .85 & & & \\
\hline
\end{tabular}

Table 4 Results of Model 2 (With-Without FX Intervention by the Central Bank) 


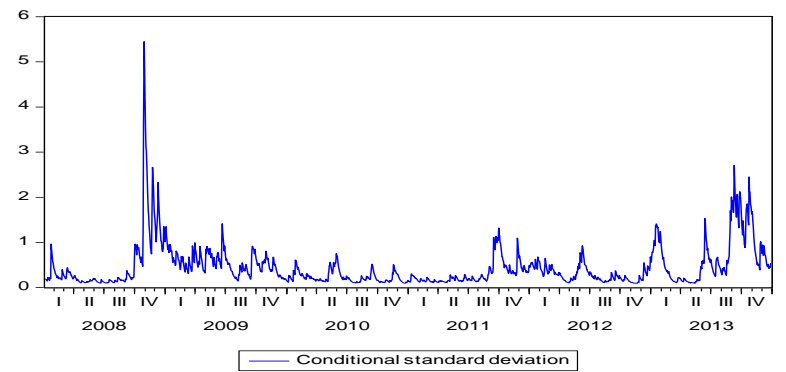

Figure 3 Conditional Standard Deviation of GARCH

The results of standard OLS estimation of equation (1) are reported in Table 2, with the test statistics applied to estimated error terms. As can be seen from the graphical representation of estimated errors (Figure 2), although addition of explanatory variables to the model relatively loosens the clustering, the ARCH effect in series is obvious. Moreover, Ljung-Box serial correlation tests show sign of autocorrelation and the test $\mathrm{p}$-values of $\mathrm{Q}^{2}$ shown in the Table 2 are all zero, resoundingly rejecting the "no ARCH" hypothesis. As for the ARCH LM test for absence of conditional heteroscedasticity, it is highly significant at any level.

Results of the Model 2 (volatility), estimated with GARCH $(1,1)$ is displayed in Table 4. According to the results of the model, the results confirm IRP theory, which suggests that an increase in real interest rate parity (RIRP) causes appreciation of the domestic currency. Furthermore, foreign exchange sale interventions lead return of exchange rate to decrease. Besides, foreign-exchange sale intervention is estimated to be negative and statistically significant, which can be interpreted as, an increase in foreign-exchange sale intervention causes Indonesian Rupiah Return to decrease. It is obvious that policy response in minimizing exchange rate volatility can be said to be effective as it can reduce the volatility of USD/IDR. On the other hand, the NDF return has positive impact on the on-shore exchange rate return. When the impact on return of exchange rate investigated, as expected, R-NDF is estimated to be positive and statistically significant, which can be interpreted as, an increase in return of NDF causes Indonesian Rupiah return to increase for more. Therefore, it is important for the central bank introducing a new policy called JISDOR (Jakarta Interbank Spot Dollar Rate) to reduce the role of NDF in driving on-shore exchange rate.

The coefficients on all three terms in the conditional variance equation are highly statistically significant. Also, as is typical of GARCH model estimates for financial asset returns data, the sum of the coefficients on the lagged squared error and lagged conditional variance is very close to unity. This implies that shocks to the conditional will be highly persistent. This can be seen by considering the equations for forecasting future values of the conditional variance using a GARCH model given in a subsequent section. A large sum of these coefficients will lead future forecast of the variance to be high for a protracted period. The conditional variance coefficients are also as one would expect. The variance intercept term ' $\mathrm{C}$ ' is very small, while the coefficient on the lagged conditional variance ('GARCH') is smaller at 0.73 when the Central Bank enter the domestic FX market.

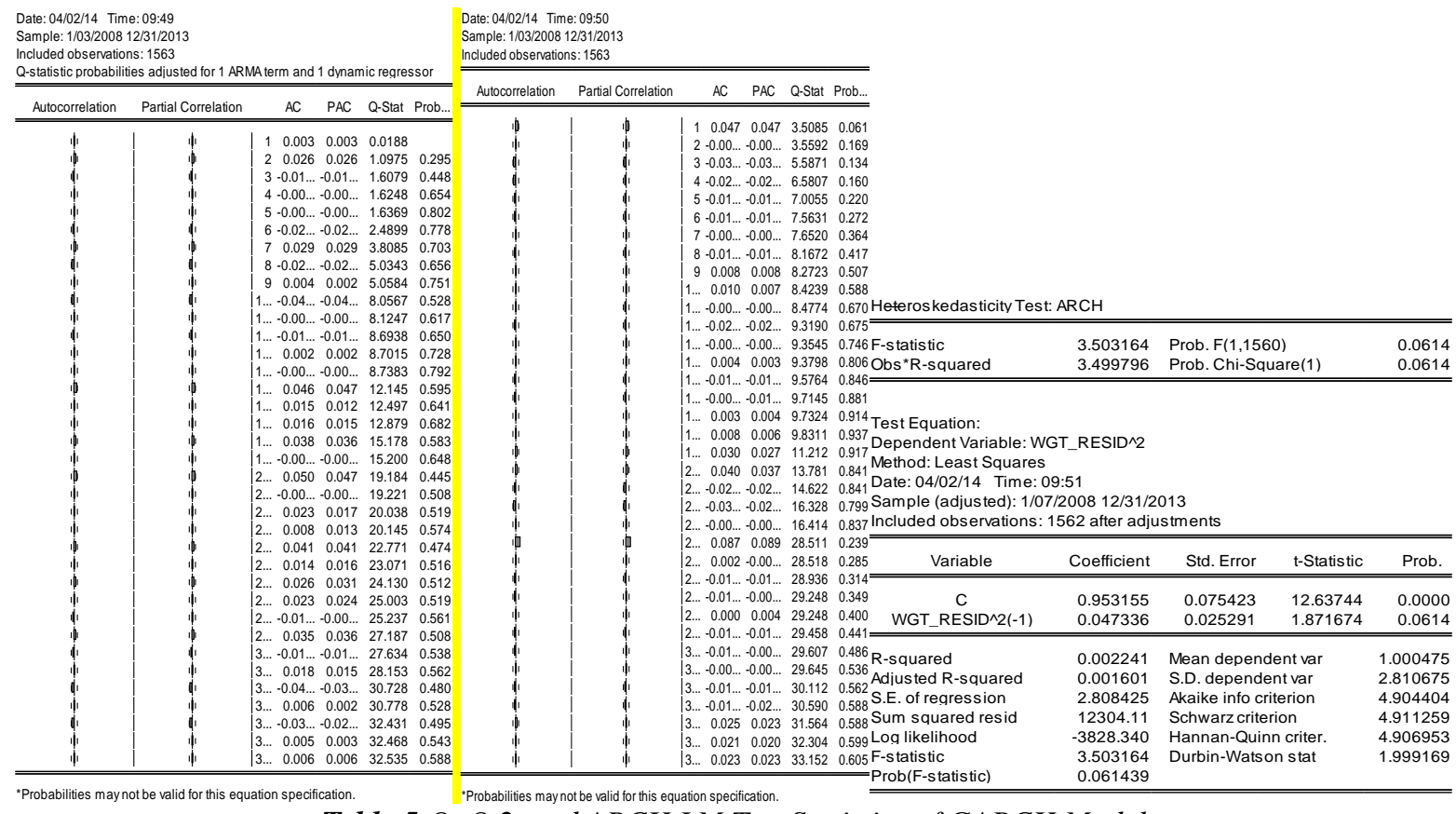

Table 5 Q, Q,2, and ARCH LM Test Statistics of GARCH Model 
As can be seen from the table, the sale interventions have significant impact on exchange rate return. That is, sale intervention cause USD/IDR return to decrease slightly. The results also suggest that return of NDF is significant and implies the increase of NDF return will increase USD/IDR return.

The Ljung-Box test statistic for the standardized error terms, $\varepsilon_{t} / h_{t}^{1 / 2}$ and the standardized squared error terms $\varepsilon_{t} / h_{t}^{1 / 2}$ from the estimated GARCH $(1,1)$ model are displayed in the Table 5 and thus do not indicate any further first or second order serial dependence. Moreover, ARCH LM test statistics approve the removal of ARCH effects from the series.

Given Bank Indonesia's objective for foreign currency intervention, efficacy is mainly assessed in relation to rupiah volatility. Rupiah volatility has diminished since free floating was adopted, suggesting the effectiveness of intervention and other monetary measures. However, in Bank Indonesia's perspective, to assess the effectiveness of foreign exchange intervention, one should examine a number of aspects that are in line with the central bank's overall objective of maintaining price stability as well as monetary and financial system stability. First, there is the question of what the objective of the exchange rate policy is - merely smoothing volatility, or also managing the path of exchange rate movement, gaining the ability to influence exchange rate expectations, and other things. Second, there is the matter of the depth and behaviour of the microstructure of the foreign exchange market, e.g. the number of players, volume of transactions, availability and variety of financial instruments, liquidity conditions and distribution across players, counter-party risks, and the infrastructure needed for efficient market functioning. The other aspect that is often important for the effectiveness of foreign exchange intervention is the adequacy of international reserves relative to the depth of the markets and the country's external vulnerability. The more reserves there are, the credibility of the central bank improved. In Indonesia's case, we view exchange rate movement as not always reflecting the economic fundamentals, let alone being consistent with the overall objective of achieving price stability and supporting financial system stability. Exchange rate overshooting occurs because of a number of factors, e.g. volatile capital flows, irrational behaviour of market players, and the microstructure conditions of the market, as well as influence from offshore markets. Thus, as stated above, the objective of foreign exchange intervention is to stabilize the exchange rate along its fundamental path. And judging from the perspective of this objective, the intervention conducted has proven able to manage the exchange rate volatility and ensure a path that is consistent with achieving the inflation target and supporting financial stability. Over the more medium term, the rupiah gradually appreciated during the period up to August 2011 and has been gradually depreciating since, reflecting overall macroeconomic developments during these two episodes in the Indonesian economy.

From the short-term perspective, the effectiveness of intervention in influencing exchange rate expectations is more difficult to assess, since the exchange rate is more susceptible to news developments and market reactions to them. In general, when market reactions are not excessive, supply and demand in the market in most cases can balance each other, and intervention may be more effective in influencing both the spot and forward exchange markets if it is used to deal with any remaining excess demand or supply in the market. Information on the distribution of spot quotations and forward forecasts among market players could be used as input when conducting intervention.

However, when news and market reactions are erratic, these two distributions tend to widen, and even their central tendencies tend to diverge from the central bank's view on where the fundamental exchange rate path should be. The spread between offshore and onshore exchange rates also tends to widen. An example is what happened to the rupiah early this year, when the news included a number of negative items, including widening current account deficits, the issue of increasing fuel subsidy burdens and fiscal sustainability, and worries about foreign exchange liquidity in the domestic market. The spread between offshore and onshore forward rates widened to as much as Rp 275 or about 2.8 percent of the Rp 9650 per US dollar exchange rate at that time (Figure 4). The spread is closing at present, as the central bank intensifies its efforts to supply foreign exchange to the market and its communications on the balance of payments situation.

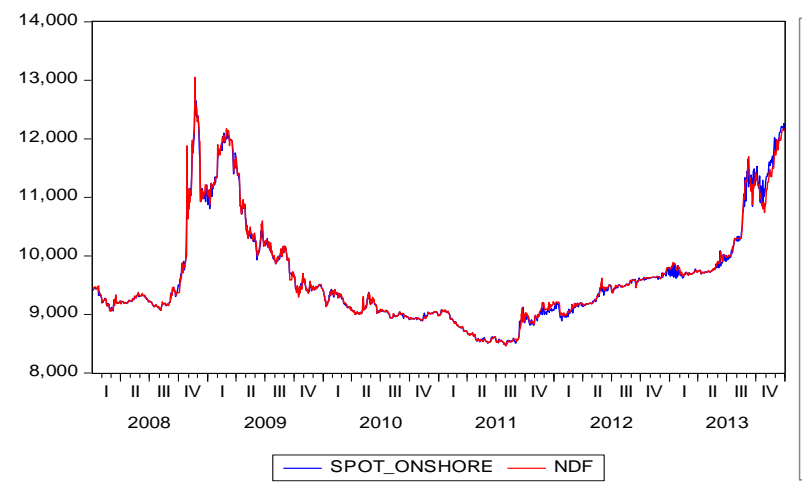

Figure 4 Exchange Rate: Onshore vs NDF

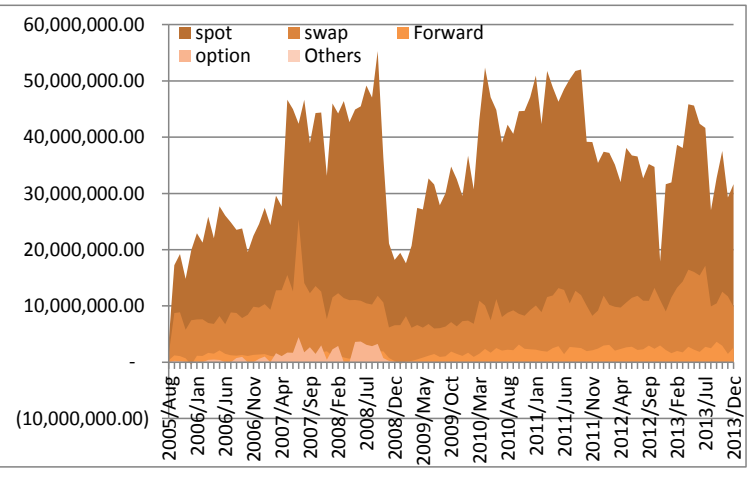

Figure 5 Volume of FX Transactions 
The microstructure of the domestic foreign exchange market also influences the effectiveness of intervention. Even though there are 72 foreign exchange banks in Indonesia, only about 22 to 38 banks actively trade in the foreign exchange market. Domestic state-owned banks constantly supply foreign exchange, while foreign banks' supply or demand depends on capital inflow/outflow. The volume of transactions is relatively small, and it tends to be larger during periods of heavy portfolio inflows (up to August 2011) but lower afterwards (Figure 5). Most transactions are spot, although forward transactions are developing. There are counter-party transaction limits, especially for smaller banks. Foreign-exchange transactions must have underlyings and are limited to domestic players only.

Under these conditions, rupiah exchange rate movements are prone to changes in perceptions and market conditions, both domestically and offshore. On one hand, the thinness of the market makes the banks heavily dependent on the central bank to absorb any excess supply in the market (during current account surplus and/or large capital inflow periods) and to supply any excess demand in the market (during current account deficit and/or capital outflow periods). Thus, the adequacy of foreign exchange reserves will increase the effectiveness of intervention, and for that reason it needs to be continuously assessed in relation to current balance of payments dynamics. On the other hand, the effectiveness of intervention will also depend on the central bank's ability to influence market expectations, since short-term exchange-rate movements are susceptible to any change in perceptions under these microstructure conditions.

The foregoing discussion points to the need for complementing foreign exchange intervention with other policies that are designed to manage the volatility of capital flows and deepen the domestic financial market. For that reason, a number of policies have been put in place in Indonesia to manage short-term and volatile capital flows, e.g. a holding period for investment in the central bank bills, limits on short-term offshore borrowing, etc. Capital flow management is guided by the following three principles. First, it must be consistent with principles regarding the foreign exchange system. The prudential measures for managing capital flows apply to both residents and non-residents, and thus they are not regarded as capital controls. Second, Bank Indonesia welcome long-term capital flows that benefit the economy, and thus our measures target short-term and speculative capital flows. Third, the measures are designed so that they can be monitored and implemented effectively.

To increase the supply of foreign exchange in the market, a regulation has been issued requiring that foreign exchange receipts from exports and offshore borrowing be repatriated to domestic banks. Continuous efforts have also been directed toward deepening the domestic foreign exchange market to include offering foreign exchange term deposits, and toward relaxing forward transactions. The most recent measure in this area is the establishment of a market reference rate for onshore foreign exchange transactions (JISDOR - Jakarta Interbank Spot Dollar Rate), including forward transactions, thus limiting the impact of the offshore NDF rate on the domestic market.

\section{Conclusion}

In this research, the sources of USD/IDR exchange rate volatility in Indonesia and the related monetary response, are analyzed. Exchange rate volatility is estimated by GARCH model with emphasis on the monetary response. Exchange rate volatility is determined by several factors such as fundamental economy or sentiment factors. In this research, Bank Indonesia foreign-exchange interventions, NDF return, and real interest rate parity, are considered and their impacts are investigated by bringing such factors together in a general framework and trying to disentangle their significant effects on exchange rate volatility. This study further confirms the assumption that Indonesia as a small open economy tend to have high and persistent exchange rate volatility when this result holds in most open emerging countries.

The fact that the vulnerability of Indonesia may be explained by the different strength it's economic fundamental. According to the results of the model, the results confirm IRP theory, which suggests that an increase in real interest rate parity causes appreciation of the domestic currency. Foreign-exchange-Sale Interventions move return of exchange rate to decrease. It is obvious that policy response by the Central Bank in minimizing exchange rate volatility can be said to be effective as it can significantly reduce the return and lagged conditional volatility of USD/IDR slightly. On the other hand, the NDF return has positive impact on the onshore exchange rate return. Therefore, it is important for the central bank introducing a new policy called JISDOR (Jakarta Interbank Spot Dollar Rate) to reduce the role of NDF in driving on-shore exchange rate. Either way, further research is needed in order to see other relevant factors that have significant impact on foreign exchange rate volatility.

\section{References}

- Agcaer. 2003, Effectiveness of Central Bank Interventions under the Floating Exchange Rate Regime: Turkish Experience.

- Akcay, O. Cevdet, C. Emre Alper and Meral Karasulu, 1997, "Currency substitution and exchange rate instability: the Turkish case", European Economic Review, 41, 827-835. 
- Akinci, Ozge, Olcay Y. Culha, Umit Ozlale and Gulbin Sahinbeyoglu, 2005a, "Causes and effectiveness of foreign exchange interventions for Turkish economy" Central Bank of Republic of the Turkey

- Akinci, Ozge, Olcay Y. Culha, Umit Ozlale and Gulbin Sahinbeyoglu, 2005b, The effectiveness of foreign exchange interventions under floating exchange rate regime for the Turkish economy: a post-crisis period analysis" Central Bank of Republic of the Turkey

- Ayhan, Duygu, 2006, "Döviz kuru rejimlerinin kur oynaklı̆̆ı üzerine etkisi: Türkiye örneği”, İktisat İşletme ve Finans, Ağustos, 64-76.

- Aysoy, Cem and Ercan Balaban, 1996, "The term structure of volatility in Turkish foreign exchange: implications for option pricing and hedging decisions", CBRT Discussion Paper No:9613,

- Baille, Richard T. and Tim Bollerslev, 1989a, "Common stochastic trends in system of exchange rates", Journal of Finance, 44(1), 167-81.

- Baillie., Bollerslev. 1989b. Baille, Richard T. and Tim Bollerslev, 1989b, "The message in daily exchange rates: a conditional-variance tale", Journal of Business and Economic Statistics, 7, 60-68.

- Baum CF, Caglayan M, and Ozkan N. 2004. Nonlinear Effects of Exchange Rate Volatility On The Volume of Bilateral Exports. Journal of Applied Econometrics. J. Appl. Econ. 19: 1-23 (2004)

- Belke A., Setzer R. 2003. Exchange Rate Variability and Labor Market Performance in the Visegrad Countries. Journal Economics of Planning Volume 36, Issue 2, pp 153-175

- Bollerslev. 1986. Generalized Autoregressive Conditional Heteroskedasticity. Journal of Econometrics.

- Bollerslev. Taylor. 1986. Generalized Autoregressive Conditional Heteroskedasticity. Journal of Econometrics Volume 31, Issue 3, April 1986, Pages 307-327

- Brooks C. 2002. Introductory Econometrics for Finance. UK: Press Syndicate of the University of Cambrige.

- Bulí, 2005. The Relationship Between Exchange Rate Volatility and Financial Market Liberalization

- Calvo, Reinhart. 2000. Fear of Floating. Quarterly Journal Economics. 117:379-408.

- Carbaugh R.J. 2013. International Economics $14^{\text {th }}$ edition. South-Western Cengage Learning.

- Chit M. M., Rizov M., Dirk W. 2010. Exchange Rate Volatility and Exports: New Empirical Evidence from the Emerging East Asian Economies. The World Economy.

- Chowdhury, AR. 1993. Does Exchange Rate Variability Depress Trade Flows? Evidence From Error Correction Models. Review of Economics and Statistics, Vol. 75, No. 4 (November 1993): 700-706. Economics Faculty Research and Publications. Marquette University.

- Choudhry, T. 2005. Exchange rate volatility and the United States exports: evidence from Canada and Japan

- Dell'Ariccia G. 1999. Exchange Rate Fluctuations and Trade Flows: Evidence from the European Union. IMF Staff Papers Vol. 46 No. 3 (September/December 1999).

- Domac, I, A. Mendoza. 2002. Is There Room for Forex Interventions under Inflation Targeting Framework? Evidence from Mexico and Turkey. Central Bank of Turkey, Discussion Paper, December.

- Engle R F. 1982. Autoregrresive Conditional Heteroskedasticity with Estimates of the Variance of UK Inflation. Econometrica. 50:987-1008.

- Guimarães, F. Roberto and Cem Karacadag, 2004, "The empirics of foreign exchange intervention in emerging market countries: the cases of Mexico and Turkey", IMF Working Paper, WP/04/123.

- Guleryuz, Gurdal, 1998, "Volatility analysis of time series", Master Thesis, Hacettepe University Social Science Institute BA.

- Kenen PB., Rodrik D. 1986. Measuring and Analyzing the Effects of Short-Term Volatility in Real Exchange Rates. The Review of Economics and Statistics, Vol. 68, No. 2 (May, 1986), The MIT Press.

- Kóbor A, Székely IP, 2004. Foreign Exchange Market Volatility in EU Accession Countries in the Run-Up to Euro Adoption: Weathering Uncharted Waters. IMF Working Paper WP/04/16

- Kocenda E. 1998. Exchange Rate in Transition. Munich Personal Repec Archive. Charles University, CERGE. MPRA Paper No. 32030, posted 5. July 2011 14:17 UTC

- Kocenda E., Valachy J. 2006. Exchange Rate Volatility and Regime Change: A Visegrad Comparison. Journal of Comparative Economics Volume 34, Issue 4, December 2006, Pages 727-753

- Koray F, Lastrapes WD, 1989. Real Exchange Rate Volatility and U.S. Bilateral Trade: A VAR Approach. The Review of Economics and Statistics, Vol. 71, No. 4 (Nov, 1989). The MIT Press

- McKenzie. 2002. The Economics of Exchange Rate Volatility Asymmetry. International Journal of Finance \& Economics Volume 7, Issue 3, pages 247-260, July 2002

- Pagan, Adrian R. and G. William Schwert, 1990, "Alternative models for conditional stock volatility", Journal of Econometrics, 45, 267-290.

- Tuna, Gulcay, 2002, "Shifts in monetary policies of TC Central Bank and exchange rate volatility: An ARCH model", Phd Thesis, Istanbul University.

- Warjiyo, P. 2005. Changing Perspectives on Exchange Rates: Theory and Policy Implications. Buletin Ekonomi Moneter dan Perbankan,. 269-289 